\title{
Spill-over attack by the gall fly, Urophora stylata, on congeners of its target weed, Cirsium vulgare
}

\author{
Michael Cripps ${ }^{1 *}$, Jovesa Navukula ${ }^{2}$, Benjamin Kaltenbach ${ }^{1}$, Chikako van Koten $^{1}$, Seona Casonato ${ }^{2}$, \\ Hugh Gourlay ${ }^{3}$ \\ ${ }^{1}$ AgResearch, Lincoln Science Centre, Private Bag 4749, Lincoln, New Zealand \\ ${ }^{2}$ Lincoln University, Pest Management and Conservation Department, PO Box 85084, Lincoln, New Zealand \\ ${ }^{3}$ Manaaki Whenua Landcare Research, PO Box 69040, Lincoln, New Zealand \\ *Corresponding author: mike.cripps@agresearch.co.nz \\ (Original submission received 19 June 2020; accepted in revised form 19 September 2020)
}

\begin{abstract}
The gall fly, Urophora stylata, was released in New Zealand in 1998 as a biocontrol agent against the thistle weed, Cirsium vulgare (Scotch thistle). In the summer of 2018, a survey was conducted to assess the field host range of the biocontrol agent in New Zealand. A random selection of 18 pasture populations under sheep and/or beef production, where $C$. vulgare was present, was surveyed to quantify the attack intensity (gall size relative to seedhead size) on $C$. vulgare, and the attack rate on other thistle weeds within the same population. At each location, seedheads were collected from $C$. vulgare and all other thistle species (Cardueae) present, which included Cirsium arvense (Californian thistle), Cirsium palustre (marsh thistle), Carduus nutans (nodding thistle), and an Arctium species (burdock). In addition to Cirsium vulgare, the gall fly was recorded on C. arvense (six locations) and $C$. palustre (one location). The probability of attack on $C$. arvense was positively correlated with attack intensity on $C$. vulgare, suggesting that attack on $C$. arvense is a 'spill-over effect' occurring where seedheads of $C$. vulgare are in limited supply.
\end{abstract}

Keywords host range, host specificity, non-target attack

\section{INTRODUCTION}

Post-release monitoring is an important part of classical biocontrol programmes. Monitoring is essential to determine the effectiveness of biocontrol agents, and the benefits of biocontrol programmes (Morin et al. 2009; Blossey 2016). It is also important to assess the safety of biocontrol agents to non-target plants including native species and crop plants of economic importance. Systematic surveys designed to assess attack on non-target plants are uncommon globally (Hinz et al. 2019) but New Zealand stands out as an exception, with several thorough assessments of non-target attack on valued native and economic plant species (Fowler et al. 2000; Paynter et al. 2004; Waipara et al. 2009). Results of non-target attack assessments in New Zealand have highlighted some cases of unanticipated attack on native species, and exotic species of minor economic importance (Paynter et al. 2008b; Withers et al. 2008). However, none of these cases of non-target attack were considered to have significant population impacts on the non-target species. Furthermore, these cases of non-target attack would have been predictable with more thorough pre-release hostrange testing, since they occurred on closely related plant species (Pemberton 2000; Paynter et al. 2008a; Paynter et al. 2015).

In addition to assessing the safety of introduced biocontrol agents, post-release monitoring can be used to assess if the pre-release host specificity testing matches the realised 'field host range' in the introduced region (Fowler et al. 2012; Schaffner et al. 2020). Prior to introducing a biocontrol agent, laboratory-based pre-release host specificity studies are carried out to define the 'fundamental host range' of the species under consideration (i.e. the group of plant species on which the biocontrol agent can complete development) (Schaffner 2001). After host specificity testing, the fundamental host range of a potential biocontrol insect is often phylogenetically defined, such as development being restricted to a genus, or tribe of plants.

Under field conditions, many plants within the fundamental host range are seldom attacked (Cristofaro et al. 2013). Biocontrol agents are unlikely to encounter some potential host plants due to different phenologies (temporal separation), or different environmental niches (spatial separation), compared to the primary host (Wapshere 1989). While temporal and spatial separation of some potential host plants can limit the realised field host range of biocontrol agents, often the field host range is limited due to the expression of preference hierarchies, where herbivorous insects preferentially utilise host plants that maximise their fitness (or actively avoid suboptimal hosts that result in reduced fitness) (Sheppard et al. 2005). Where utilisation of less preferred host plants occurs under field conditions, it is often a result of 'spill-over attack'. Spill-over attack is defined as transient utilisation of less preferred species, as a result of depletion of the primary host plant(s) (Hinz et al. 2020). In other words, it is attack that is unlikely to occur when the primary resource is plentiful.

The purpose of the present study was to assess the field host range of the gall fly, Urophora stylata (F.), a biocontrol agent introduced to New Zealand for control of the thistle weed, Cirsium vulgare (Savi) Tenore (Scotch thistle). The 
fly is native to the Palearctic region, where it is commonly reported to attack the seedheads of $C$. vulgare, its primary host plant (Redfern 1968). The fly oviposits eggs between the bracts of developing seedheads, or sometimes inserts eggs in the tips of florets. The larvae hatch as second instars and move down the floret tubes, and then feed on the developing seeds. Multiple larvae often develop in a single seedhead, creating a hardened multi-chambered gall within the seedhead. By mid-summer the next generation of adults emerge, completing a partial second generation per year (Redfern 1968).

Surveys in central Europe have recorded U. stylata from Cirsium and Carduus species (Zwölfer 1965; Korneyev \& White 2000). However, different biotypes of U. stylata have been reported from its native range, including a biotype from the eastern Mediterranean region considered to be oligophagous, developing on a wide range of Cardueae host plants (Knio et al. 2002).

Pre-release host specificity testing carried out in the native range, evaluated oviposition of the fly on 44 test plant species (including 10 non-Cardueae species). Oviposition by the fly was reported on three Cardueae test plants (Arctium tomentosum Miller, Carduus acanthoides L., and Onopordum acanthium L.), but development was completed only on the primary host plant, $C$. vulgare (Zwölfer, unpublished) ${ }^{1}$. The host specificity testing was carried out at CABI Switzerland (Delémont) exclusively using the Swiss Jura biotype of the fly, which was considered to be highly specific to $C$. vulgare (Zwölfer, unpublished) ${ }^{1}$.

Additional pre-release host specificity testing was carried out in New Zealand and Australia, primarily to ensure safety to native plant species. In New Zealand, the closest native relatives to Cardueae belong to the Cichorieae tribe and include Sonchus species. While Sonchus species are very distantly related to Cirsium vulgare (Funk et al. 2009), and unlikely to be attacked, it was considered prudent to test these species since some are culturally valued as traditional food plants (known to Māori as pūhā), and classified as threatened, or nationally vulnerable species (de Lange 2020). As expected, no attack was detected on native Sonchus species (Table 1). Of three thistle weeds (Cirsium arvense (L.) Scop., Carduus nutans L. and Silybum marianum (L.) Gaertn.) tested in addition to Cirsium vulgare, attack was detected only on Cirsium arvense (Table 1). In Australia, there are two Cardueae species recorded as native, Rhaponticum australe (Gaudich.) Soskov and Saussurea lyrata (Bunge) Franch., although their native status is doubtful (Hidalgo et al. 2006; Susanna \& Garcia-Jacas 2007). No attack was reported on these Cardueae species, or an additional 10 species from nine different Asteraceae tribes (Harris et al, unpublished) ${ }^{2}$.

In New Zealand, U. stylata was released in 1998 via a shipment from Australia, followed by a supplemental release sourced from the USA in 1999 (Winston et al. 2014). The original sources of $U$. stylata released in Australia and North America were collected from populations of the fly from its native range in France, Germany, and Switzerland. Thus, it is likely that the fundamental host range of $U$. stylata released in New Zealand corresponds with host records from surveys in central Europe, and that the fly is restricted to Carduus and Cirsium species. Urophora stylata is the only species deliberately released for biocontrol of Cirsium vulgare in New Zealand, although the weevils, Rhinocyllus conicus (F.) and Trichosirocalus horridus (Panzer), have been reported to attack the weed (Zwölfer \& Harris 1984; Groenteman et al. 2008). Rhinocyllus conicus was released along with Urophora solstitialis (L.) to control thistle weeds in New Zealand. Both are seedhead-feeding biocontrol agents but diverge in their host range. Urophora solstitialis has not been recorded on any host plants other than Carduus nutans in New Zealand, although closely related Carduus species are within the its host range (Woodburn 1993; Korneyev \& White 2000). Rhinocyllus conicus is known to have an oligophagous host range attacking many plants in the subtribe Carduinae (true thistles) (Zwölfer 1965; Zwölfer \& Harris 1984).

Table 1 Summary results of multi-choice tests carried out with Urophora stylata at Lincoln, New Zealand, summer 1997-1998. This table is reproduced from an unpublished report (Harris et al, unpublished) ${ }^{2}$ with permission from Manaaki Whenua Landcare Research.

\begin{tabular}{llrrrr}
\hline Test plant species & Common name & $\begin{array}{c}\text { No. } \\
\text { plants }\end{array}$ & $\begin{array}{c}\text { No. seed- } \\
\text { heads }\end{array}$ & $\begin{array}{c}\text { Seedheads } \\
\text { attacked }\end{array}$ & $\begin{array}{c}\text { No. } \\
\text { larvae }\end{array}$ \\
\hline Cirsium vulgare (Savi) Tenore & Scotch thistle & 14 & 42 & 27 & 83 \\
Cirsium arvense (L.) Scop. & Californian thistle & 4 & 76 & 2 & 3 \\
Carduus nutans L. & nodding thistle & 6 & 24 & 0 & 0 \\
Silybum marianum (L.) Gaertn. & variegated thistle & 6 & 226 & 0 & 0 \\
Sonchus novae-zelandiae (Hook.f.) Garn.-Jones & dryland sow thistle & 5 & 7 & 0 & 0 \\
[= Kirkianella novae-zelandiae (Hook.f.) Allan] & & & & & 0 \\
Sonchus kirkii Hamlin & New Zealand sow thistle & 6 & 43 & 0 & 0 \\
Picris sp. & & 3 & 16 & 0 & 0 \\
\hline
\end{tabular}

${ }^{1}$ Zwölfer H 1972. Investigations on Urophora stylata Fabr., a possible agent for the biological control of Cirsium vulgare in Canada. Weed projects for Canada. [Commonwealth Institute of Biological Control Progress Report 29] 20 p.

${ }^{2}$ Harris RJ, Rose EAF, Gourlay AH 1998. Introduction of Urophora stylata for biological control of Scotch thistle Cirsium vulgare: An importation impact assessment. [Landcare Research Contract Report: LC9798/096] 22 p. 
There are no native thistle species (Cardueae) in New Zealand (Webb et al. 1988) so the only non-target species of concern were exotic crop species of economic importance. Paynter et al. (2004) reported no non-target attack by introduced thistle biocontrol agents; and specifically, no attack on commercial production of artichoke (Cynara scolymus L.) by the seedhead gall fly, U. stylata. While Paynter et al. (2004) assessed potential non-target attack by $U$. stylata in New Zealand, it remained uncertain to what extent $U$. stylata might attack related thistle weeds. Thus, as part of a recent post-release assessment to determine the impact of U. stylata on seed production of Cirsium vulgare (Cripps et al. 2020), attack on co-occurring thistle species within the same population as the target weed was assessed. The field hosts reported here are considered in relation to the prerelease host specificity testing and the likely fundamental host range of $U$. stylata released in New Zealand.

\section{MATERIALS AND METHODS}

\section{New Zealand host-specificity testing (summer 1997-1998)}

Pre-release host specificity testing of Urophora stylata was carried out in a quarantine facility under controlled environment conditions ( $16 \mathrm{~h}$ light at $22^{\circ} \mathrm{C}$ and $60 \% \mathrm{RH}$, alternating with $8 \mathrm{hr}$ dark at $13^{\circ} \mathrm{C}$ and $70 \% \mathrm{RH}$ ). Each of seven replicate cages contained two Cirsium vulgare plants and a single plant of up to five of other test species (Table 1). Four to six females and four or five males of $U$. stylata were placed in each cage for four days. The test plants were maintained until the end of their flowering period, and then all seedheads were dissected and inspected for the presence of $U$. stylata larvae.

\section{Collection of seedheads}

The populations selected for this study were part of a nationwide survey to assess the impact of $U$. stylata on seed production of Cirsium vulgare in New Zealand pastures. Details of the selected populations are given in Cripps et al. (2020) and briefly summarised here. Twenty locations were randomly selected from the 34,167 farms designated as sheep, beef, or sheep + beef properties in the 2015 AgriBase dataset (Assure Quality, New Zealand), and stratified to ensure an equal number of populations in both the North and South Islands of the country (10 in the South Island, and 10 in the North Island). For the current study, the seedheads for assessing U. stylata attack on co-occurring thistle species were taken from 18 locations, i.e. the first two surveyed locations by Cripps et al. (2020) (Lincoln and Oxford, Canterbury) were excluded. Only pasture land designated as sheep and/or beef production was included since this is where the weed is most problematic (Kelly \& Popay 1985; Bourdôt \& Kelly 1986). The randomly selected locations were assessed in consultation with the relevant Beef+Lamb NZ farm extension manager for each region, and the nearest suitable location known to have $C$. vulgare present was selected for surveying. Of the randomly selected 18 C. vulgare populations, 15 had additional thistle species present (Table 2).
To assess potential attack on other thistle species, seedhead collections were carried out for all thistle species (Cardueae) present at the surveyed locations and included Cirsium arvense, Cirsium palustre (L.) Scop., Carduus nutans, and an Arctium species (Table 2). These Cardueae species have similar phenologies to Cirsium vulgare, producing flower buds from spring to summer when the fly is active (November to February) (Webb et al. 1988; Cripps et al. 2020). A maximum of ten plants (or shoots in the case of C. arvense) of each species were haphazardly selected and three post-flowering seedheads were collected (maximum of 30 seedheads per thistle species for each surveyed location). These seedhead samples were kept in ventilated containers in a laboratory at AgResearch (Lincoln), maintained at constant temperature $\left(20^{\circ} \mathrm{C}\right)$ and exposed to indirect natural ambient light. The containers were periodically inspected for the presence of adult biocontrol agents (U. stylata, U. solstitialis, and R. conicus) from 25 May 2018, when the first adult emergence was observed, until 23 January 2019 after which no more emergence of adult biocontrol agents was observed. At each inspection time, all adult biocontrol agents were counted, and removed from the containers.

Supplemental to this systematic survey, an opportunistic collection of thistle seedheads from three locations in the Gisborne region was carried out in December 2019. At each of these locations, Cirsium vulgare was present along with at least one other thistle species, including Cirsium arvense, Carduus tenuiflorus W. Curtis, and Silybum marianum. As described above, three seedheads from ten individual plants of each thistle species present were collected, maintained in boxes in the laboratory, and inspected for emergence of adult biocontrol agents (Table 3 ).

\section{Attack intensity on the primary host}

The mean attack intensity for each Cirsium vulgare population was determined from seedhead dissections. At each population, a maximum of 30 individual plants were haphazardly selected for collection of seedheads for later dissection. At populations with less than 30 plants, all plants present in the population were surveyed. From each plant, up to three seedheads were collected for subsequent dissection in the laboratory (Table 2). Only seedheads visually assessed to be in the post-flowering growth stage were collected. For plants with less than three seedheads in the post-flowering stage, all seedheads in this growth stage were collected. The seedheads were refrigerated at $4^{\circ} \mathrm{C}$ until they were dissected in the laboratory. Each seedhead was cut in half, and the receptacle diameter ( $\mathrm{mm}$ ) was measured. If a gall was present, the gall diameter was measured ( $\mathrm{mm}$ ), and the percentage of each seedhead that was occupied by a gall $(\%$ galled $=$ gall diameter $/$ seedhead diameter $\mathrm{x} 100)$ was calculated and used as the measure of 'attack intensity'. The percentage of a seedhead occupied by a gall is a good measure of attack intensity since gall size is directly related to the number of larvae developing within the gall (Harris \& Wilkinson 1984).

\section{Statistical analyses}

Presence of $U$. stylata attack on Cirsium arvense per 
Table 2 Locations of thistle species populations surveyed for attack by seedhead-feeding biocontrol agents present in New Zealand. At each location, three seedheads were collected from 10 plants of each species (total of 30 seedheads per thistle species for each population), except for Cirsium vulgare at Ararimu where only three plants were present and six seedheads collected in total, and for the Arctium sp. at Rotorua where only one plant was present from which 30 seedheads were collected.

\begin{tabular}{|c|c|c|c|c|c|}
\hline \multirow[b]{2}{*}{ Collection date } & \multirow[b]{2}{*}{ Location } & \multirow[b]{2}{*}{ Thistle species } & \multicolumn{3}{|c|}{ No. adults emerged } \\
\hline & & & Urophora stylata & Urophora soltitialis & Rhinocyllus conicus \\
\hline \multirow{3}{*}{$22 / 02 / 2018$} & Waimate & Carduus nutans & 0 & 390 & 13 \\
\hline & & Cirsium arvense & 0 & 0 & 0 \\
\hline & & Cirsium vulgare & 29 & 0 & 0 \\
\hline \multirow[t]{2}{*}{$23 / 02 / 2018$} & Portobello & Cirsium arvense & 0 & 0 & 0 \\
\hline & & Cirsium vulgare & 0 & 0 & 0 \\
\hline $27 / 02 / 2018$ & Dobson Moana & Cirsium vulgare & 0 & 0 & 0 \\
\hline \multirow[t]{2}{*}{$27 / 02 / 2018$} & Kumara & Cirsium vulgare & 0 & 0 & 0 \\
\hline & & Cirsium palustre & 0 & 0 & 0 \\
\hline $28 / 02 / 2018$ & Mt Somers $^{1}$ & Carduus nutans & 0 & 81 & 3 \\
\hline \multirow[t]{2}{*}{$28 / 02 / 2018$} & Methven & Cirsium arvense & 0 & 0 & 0 \\
\hline & & Cirsium vulgare & 58 & 0 & 0 \\
\hline \multirow[t]{2}{*}{$2 / 03 / 2018$} & Dipton & Cirsium arvense & 0 & 0 & 0 \\
\hline & & Cirsium vulgare & 0 & 0 & 0 \\
\hline \multirow[t]{3}{*}{$2 / 03 / 2018$} & Happy Valley & Cirsium arvense & 0 & 0 & 0 \\
\hline & & Cirsium vulgare & 0 & 0 & 0 \\
\hline & & Cirsium palustre & 0 & 0 & 0 \\
\hline $5 / 03 / 2018$ & Portland & Cirsium vulgare & 64 & 0 & 4 \\
\hline $5 / 03 / 2018$ & Tangiteroria & Cirsium vulgare & 41 & 0 & 5 \\
\hline $6 / 03 / 2018$ & Ararimu & Cirsium arvense & 8 & 0 & 0 \\
\hline \multirow[t]{3}{*}{$6 / 03 / 2018$} & Maramarua & Cirsium vulgare & 26 & 0 & 0 \\
\hline & & Cirsium arvense & 17 & 0 & 1 \\
\hline & & Cirsium vulgare & 60 & 0 & 1 \\
\hline \multirow[t]{3}{*}{$7 / 03 / 2018$} & Rotorua & Arctium sp. & 0 & 0 & 0 \\
\hline & & Cirsium arvense & 1 & 0 & 0 \\
\hline & & Cirsium vulgare & 128 & 0 & 0 \\
\hline \multirow[t]{2}{*}{$8 / 03 / 2018$} & Moawhango & Cirsium arvense & 3 & 0 & 0 \\
\hline & & Cirsium vulgare & 69 & 0 & 2 \\
\hline \multirow[t]{2}{*}{$8 / 03 / 2018$} & Taihape & Cirsium arvense & 9 & 0 & 0 \\
\hline & & Cirsium vulgare & 39 & 0 & 0 \\
\hline $8 / 03 / 2018$ & Fordell $^{2}$ & Cirsium arvense & 36 & 0 & 0 \\
\hline \multirow[t]{3}{*}{$9 / 03 / 2018$} & Hastwell & Cirsium arvense & 0 & 0 & 0 \\
\hline & & Cirsium vulgare & 6 & 0 & 0 \\
\hline & & Cirsium palustre & 1 & 0 & 0 \\
\hline \multirow[t]{2}{*}{$9 / 03 / 2018$} & Rangitumau & Cirsium arvense & 0 & 0 & 0 \\
\hline & & Cirsium vulgare & 5 & 0 & 0 \\
\hline
\end{tabular}

${ }^{1}$ At the Mt Somers population, Cirsium vulgare was present, and assessed for larval attack intensity by Urophora stylata (see Cripps et al. 2020), but extra seedheads to assess adult biocontrol agent emergence were not collected.

${ }^{2}$ At the Fordell population, 15 Cirsium vulgare plants were present from which all available seedheads in the post-flowering stage were collected for dissection to assess the larval attack intensity by Urophora stylata (see Cripps et al. 2020). 
Table 3. Supplemental thistle populations surveyed for attack by seedhead-feeding biocontrol agents present in New Zealand.

\begin{tabular}{lllccc}
\hline & & \multicolumn{3}{c}{ No. adults emerged } \\
\hline Collection date & Population & Thistle species & Urophora stylata & Urophora solstitialis & Rhinocyllus conicus \\
\hline $4 / 12 / 2019$ & Ngatapu & Cirsium vulgare & 39 & 0 & 1 \\
& & Carduus tenuiflorus & 0 & 0 & 3 \\
$5 / 12 / 2019$ & \multirow{5}{*}{ Tangihanga Station } & Cirsium vulgare & 1 & 0 & 0 \\
& & Cirsium arvense & 0 & 0 & 0 \\
& & Carduus tenuiflorus & 0 & 0 & 0 \\
$6 / 12 / 2019$ & \multirow{3}{*}{ Whatatutu } & Silybum marianum & 0 & 0 & 0 \\
& & Cirsium vulgare & 21 & 0 & 0 \\
\hline
\end{tabular}

population was expressed as a binary response (yes or no) and the relationship of this response with attack intensity on Cirsium vulgare in the corresponding populations was analysed using a generalised linear model (GLM) with a binomial distribution through a logit link function. The GLM consisted of the attack intensity covariate only, and the analysis estimated the relationship between the probability of attack on $C$. arvense and attack intensity on $C$. vulgare. The number of $U$. stylata per seedhead of $C$. arvense was calculated for each population (rate of attack) and the relationship between this rate and attack intensity on $C$. vulgare was analysed using polynomial regression. A quadratic equation modelled the observed nonlinear pattern and restricted the rate of attack to be equal or greater than zero. Statistical analyses were performed with Minitab version 16.

\section{RESULTS}

Urophora stylata was detected in 13 of the 18 randomly selected Cirsium vulgare populations. Thistle species other than $C$. vulgare were present at 15 of the 18 locations. At locations where there was no attack by $U$. stylata on $C$. vulgare, there was no attack recorded on any other thistle species. Cirsium arvense was present at 13 locations, of which 10 had $U$. stylata detected. Attack by U. stylata on $C$. arvense was recorded at six of the 10 locations where both were present (Table 2).

The probability of attack on $C$. arvense was positively correlated with attack intensity (i.e. mean percentage occupation of seedheads by $U$. stylata galls) on the primary host, $C$. vulgare $\left(\chi^{2}=8.24, \mathrm{df}=1, \mathrm{P}=0.004\right)$ (Fig. 1$)$. The maximum attack intensity where no spill-over attack occurred on $C$. arvense was $18 \%$; and the minimum attack intensity where spill-over occurred was $42 \%$. The inflection point in the logistic model is at 29\% (95\% CI=28\%, 30\%) attack intensity on $C$. vulgare. Beyond this attack intensity, the probability of spill-over attack occurring on $C$. arvense is greater than the probability of it not occurring. At an attack intensity of $50 \%$ or more on the primary host plant, spillover attack on $C$. arvense is predicted to be a near certainty (Fig. 1). As the intensity of attack on $C$. vulgare increased, the rate of attack (U. stylata per seedhead) on C. arvense also increased $\left(\mathrm{F}_{2,11}=6.34, \mathrm{P}=0.015\right)$ (Fig. 2). The mean attack rates on $C$. arvense ranged from 0.1 to $1.2 \mathrm{U}$. stylata per seedhead.

The only other thistle species attacked by U. stylata in this study was Cirsium palustre. One specimen of $U$. stylata emerged from the $C$. palustre seedheads collected from the Hastwell field site (Table 2). At this location there was relatively low attack intensity on $C$. vulgare (mean of $18 \%$ ), and no attack on $C$. arvense detected, despite its presence there. From the supplemental surveys carried out in the Gisborne region, no attack by U. stylata was recorded on other thistle species (Cirsium arvense, Cardus tenuiflorus, or Silybum marianum), despite attack recorded on Cirsium vulgare at these locations (Table 3 ).

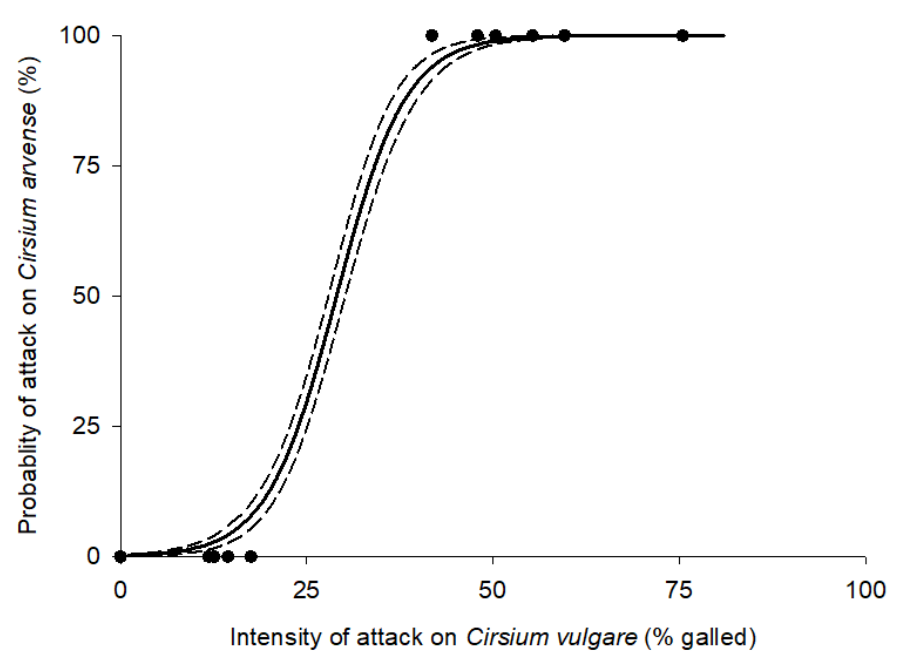

Figure 1 Probability of attack on Cirsium arvense in relation to the mean attack intensity on the primary host plant, Cirsium vulgare. The attack intensity values are from 13 randomly selected populations of $C$. vulgare where $C$. arvense was also present. The relationship (solid line) is described by the logistic equation: Probability $(\%)=100 /(1+\exp$ $(6.230-0.215 \times$ attack intensity) $)$. Dashed lines depict the 95\% confidence bands. 


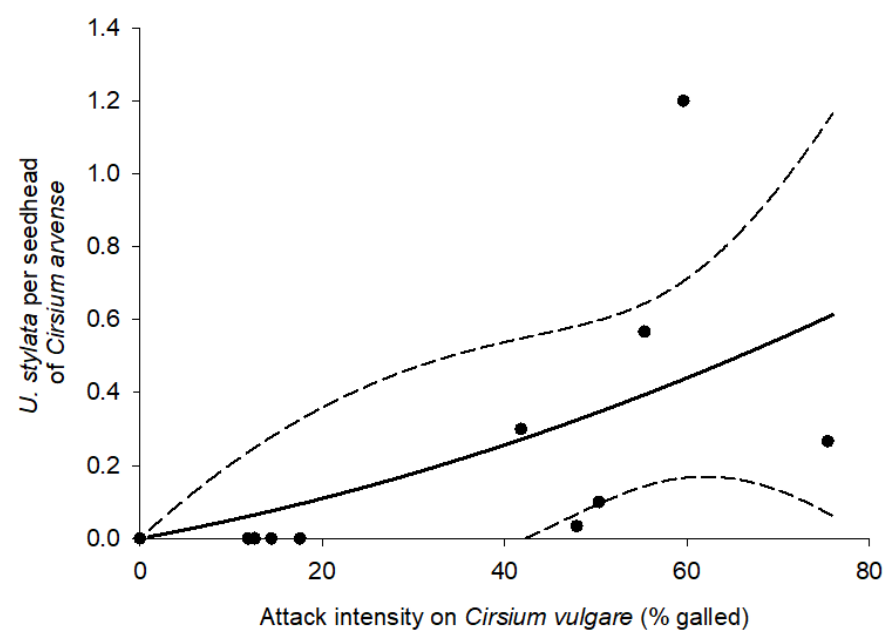

Figure 2 Mean number of Urophora stylata emerged from seedheads of Cirsium arvense in relation to the mean attack intensity on the primary host plant, Cirsium vulgare. The mean values are calculated from 13 randomly selected populations of $C$. vulgare where $C$. arvense was also present. The relationship (solid line) is described by the quadratic equation: U. stylata per seedhead $=4.56 \times 10^{-3}$ (Attack intensity) $+4.6 \times 10^{-5}$ (Attack intensity) ${ }^{2}$. Dashed lines depict the $95 \%$ confidence bands.

\section{DISCUSSION}

This study has documented that Cirsium arvense and Cirsium palustre are field host plants of the biocontrol agent, Urophora stylata, released in New Zealand for control of the weed, Cirsium vulgare. Attack on these congeneric hosts was predictable based on native range records and pre-release host specificity testing in New Zealand but the extent of host utilisation under field conditions was unknown. At least in the case of $C$. arvense, the data from this survey suggest that utilisation of this host plant is limited to spillover attack (sensu Hinz et al. 2019). This situation contrasts with full utilisation, where a biocontrol agent can sustain its population on an alternative host plant, even in the absence of its primary host. In this study we did not survey $C$. arvense in the absence of $C$. vulgare, and therefore cannot say for certain if $U$. stylata can fully utilise this or other congeneric hosts. While we did not specifically seek out populations of $C$. arvense occurring in the absence of $C$. vulgare, such populations in New Zealand would be difficult to find, since the co-occurrence of the two species is common (Bourdôt \& Kelly 1986; Klinkhamer \& de Jong 1993).

The pattern of attack on Cirsium arvense is consistent with spill-over at all 13 locations surveyed in this study where both $C$. arvense and $C$. vulgare were present. That is, attack on $C$. arvense occurred only at locations where attack intensity on the primary host was high, and never occurred where attack intensity on the primary host was low. At an attack intensity of $50 \%$ on the primary host, the predicted probability of spill-over attack on $C$. arvense is nearly $100 \%$. While this degree of attack intensity is unlikely to directly cause spill-over attack, it is probably a good indicator of a point where the preferred resource is in limited supply. Previous studies have reported that the seedhead resource tends to be underutilised by U. stylata (Harris \& Wilkinson 1984; Cripps et al. 2020), and that intraspecific competition among developing larvae is negligible (Michaelis 1986). How U. styalta avoids competition within the spatially constrained niche of the seedhead is unclear, but there is no evidence that females avoid ovipositing into already occupied seedheads. In fact, females will readily oviposit into seedheads that already contain eggs from other females (Michaelis 1986). Cripps et al. (2020) hypothesised a critical 'close-off time' during gall formation that might exclude subsequent larvae from entering the receptacle area of the seedhead, and thereby avoid competition.

The critical close-off time hypothesis may explain the underutilisation of seedheads but does not provide an explanation for the spill-over effect, or more precisely, what is causing the fly to use an alternative host that is likely suboptimal. It is possible that the spill-over effect is caused by territorial conflicts between males. Males of U. stylata (and other tephritid species) are known to establish territorial breeding grounds that they defend against conspecific rival males (Headrick \& Goeden 1994; Daniels 2004). Harris (1989) observed a volatile substance secreted by some male Urophora biocontrol agents, including U. stylata and its sister species, Urophora cardui (L.), and speculated that it might be important for locating mates. The behaviour of U. stylata has not been thoroughly studied, but for $U$. cardui the marking pheromone was found to attract both males and females. Females use the pheromone to find mates, and males use it to find safe spaces (i.e. where a male is present, predators are likely absent) (Frenzel et al. 1990; Frenzel \& Brandl 1991; Daniels 2004). At high population densities of $U$. stylata (or at least high relative to the number of $C$. vulgare plants), the frequency of male territorial conflicts may increase, forcing some males to establish territories on suboptimal host plants, such as $C$. arvense.

The rate of attack (U. stylata per seedhead) on Cirsium arvense also increased with increasing attack intensity on C. vulgare, indicating that it is not just the probability of spill-over attack that increases, but also the degree of spillover attack. Overall, the attack rates on $C$. arvense were low, with average attack rates typically much less than one per seedhead. However, the rate of attack on $C$. arvense was high at the Fordell field site, where only $15 C$. vulgare plants were present. At this location the rate of attack on $C$. arvense was 1.2 U. stylata per seedhead. This was somewhat surprising since typically when $U$. stylata attacks $C$. arvense there is only one larva per seedhead (M. Cripps, personal observation). The attack rate on $C$. arvense at the Fordell site indicates that there are occasional cases of more than one larva per C. arvense seedhead, likely where the primary host is very limited.

While the pattern of attack on Cirsium arvense is indicative of spill-over, the data are too limited to determine if the attack on $C$. palustre is a spill-over effect. From this survey, one specimen of $U$. stylata was reared from $C$. palustre, but it is worth noting that this occurred at the only field site where both $U$. stylta and C. palustre were present. Attack intensity on the primary host was low at this location (18\%), and no attack was recorded on $C$. arvense. Thus, it is possible that if C. palustre was present at a site with high attack intensity on 
C. vulgare there could be greater utilisation of this species.

Attack on Cirsium arvense and C. palustre was predictable, based on historical field host records from the native range, rather than the original host specificity testing carried out in Europe. The pre-release host specificity testing was carried out with one biotype of $U$. stylata (the Swiss Jura biotype). This biotype was considered to be monophagous, only attacking $C$. vulgare (Zwölfer, unpublished) ${ }^{1}$. Indeed, both $C$. arvense and $C$. palustre were included in the host specificity testing and were not accepted for oviposition. However, the biotype(s) released in North America, and subsequently New Zealand, were collected from populations of the fly in France, Germany, and Switzerland (Harris \& Wilkinson 1984; Winston et al. 2014), and match the somewhat broader field host range of $U$. stylata known from central Europe.

The disconnection between the host range of the biotype tested and the biotype released is an obvious inadequacy of the specificity testing. However, it is important to recognise that in the early 1970s, the main purpose of host specificity testing was to determine the safety to non-target plants of economic significance (Fowler et al. 2004; Hinz et al. 2014), in this case artichoke and safflower (Carthamus tinctorius L.) (Zwölfer, unpublished) ${ }^{1}$. In New Zealand and Australia, where the fly was released much later (1990s), additional host specificity testing ensured safety to native plant species (Harris et al, unpublished) ${ }^{2}$. The specificity testing in New Zealand recorded Cirsium arvense as a host, which was not considered problematic, since there are no native thistle species, and the bulk of introduced thistles are either current or potential weeds of economic significance (Cripps et al. 2013). However, the host specificity testing for U. stylata released in North America relied exclusively on the European study (Zwölfer, unpublished) ${ }^{1}$ that was carried out at a time when testing the safety of biocontrol agents on native species was not common practice (Fowler et al. 2004; Hinz et al. 2014). In North America, where there are numerous native Cirsium species (some of which are classified as rare or endangered (Eckberg et al. 2017)), this inadequacy in the original host testing could be problematic. To date, we are unaware of any records of non-target attack by U. stylata on native Cirsium species in North America, although it is uncertain to what extent, if any, this has been investigated. Possible non-target spill-over attack by $U$. stylata on native Cirsium species in North America, particularly at sites with C. vulgare present, would be worthwhile to investigate.

\section{ACKNOWLEDGEMENTS}

We thank Ghislaine Cortat (CABI Switzerland) for providing the unpublished host specificity report by Zwölfer ${ }^{1}$, and Jonty Mills for assistance counting adult emergence from the supplemental seedhead collections. We thank Chris Hunt (AgResearch) for assistance with the random selection of survey locations. We thank Sarah O'Connell, Laura Gray, Alison Whiteford, and Maria Shanks (Beef+Lamb NZ farm extension managers) for contacting farmers to survey the selected thistle populations. This study was funded by the AgResearch Strategic Science Investment Fund project, Pasture Weed Ecology and Management (Contract A21248D, New Zealand Ministry for Business, Innovation, and Employment).

\section{REFERENCES}

Blossey B 2016. Measuring and evaluating ecological outcomes of biological control introductions. In: van Driesche RG, Simberloff D, Blossey B, Causton C, Hoddle M, Wagner DL, Marks CO, Heinz KM, Warner KD Eds. Integrating Biological Control into Conservation Practice, John Wiley \& Sons Ltd. Pp. 161-188. https:// doi.org/10.1002/9781118392553.ch8

Bourdôt GW, Kelly D 1986. Density and cover estimates of some non-palatable herbaceous pasture weeds. Proceedings of the New Zealand Weed and Pest Control Conference 39: 183-186. https://doi.org/10.30843/ nzpp.1986.39.9375

Cripps M, Navukula J, Casonato S, van Koten C 2020. Impact of the gall fly, Urophora stylata, on the pasture weed, Cirsium vulgare, in New Zealand. BioControl 65: 501513. https://doi.org/10.1007/s10526-020-10007-0

Cripps MG, Bourdôt GW, Fowler SV 2013. Sleeper thistles in New Zealand: status and biocontrol potential. New Zealand Plant Protection 66: 99-104. https://doi. org/10.30843/nzpp.2013.66.5715

Cristofaro M, De Biase A, Smith L 2013. Field release of a prospective biological control agent of weeds, Ceratapion basicorne, to evaluate potential risk to a nontarget crop. Biological Control 64: 305-314. https:// doi.org/10.1016/j.biocontrol.2012.11.001

Daniels W 2004. The complex foraging strategy of the specialised gall fly Urophora cardui (Diptera:Tephritidae) for host plants (Cirsium arvense, Asteraceae). Unpublished thesis, Universität Bayreuth. 180 p.

de Lange PJ 2020. Sonchus kirkii Fact Sheet. New Zealand Plant Conservation Network. Accessed 4 June 2020 from: $\quad$ https://www.nzpcn.org.nz/flora/species/ sonchus-kirkii/

Eckberg J, Lee-Mäder E, Hopwood J, Jordan SF, Borders B 2017. Native Thistles: A Conservation Practitioner's Guide. Portland, Oregon, The Xerces Society for Invertebrate Conservation. $92 \mathrm{p}$.

Fowler SV, Syrett P, Hill RL 2000. Success and safety in the biological control of environmental weeds in New Zealand. Austral Ecology 25: 553-562. https://doi. org/10.1046/j.1442-9993.2000.01075.x

Fowler SV, Gourlay AH, Hill RH, Withers T 2004. Safety in New Zealand weed biocontrol: a retrospective analysis of host-specificity testing and the predictability of impacts on non-target plants. In: Cullen JM, Briese DT, Kriticos DJ, Lonsdale WM, Morin Let al. Ed. Proceedings of the XI International Symposium on Biological Control of Weeds. Canberra, Australia, CSIRO Entomology. Pp. 265-270.

Fowler SV, Paynter Q, Dodd S, Groenteman R 2012. How can ecologists help practitioners minimize nontarget effects in weed biocontrol? Journal of Applied Ecology 49: 307-310. https://doi.org/10.1111/j.13652664.2011.02106.x

Frenzel M, Dettner K, Boland W, Erbes P 1990. Identification and biological significance of 4-methyl-3Z,5hexadienoic acid produced by males of the gall-forming tephritids Urophora cardui (L.) and Urophora stylata (Fab.) (Diptera: Tephritidae). Experientia 46: 542-547. 
https://doi.org/10.1007/BF01954261

Frenzel M, Brandl R 1991. The biological significance of 4-methyl-3Z,5-hexadienoic acid in Urophora cardui (L.) (Dipt., Tephritidae). Journal of Applied Entomology 111: 172-178. https://doi.org/10.1111/j.1439-0418.1991. tb00308.x

Funk VA, Susanna A, Stuessy TF, Robinson H 2009. Classification of Compositae. In: Funk VA, Susanna A, Stuessy TF, Bayer RJ Ed. Systematics, Evolution, and Biogeography of Compositae. University of Vienna, Vienna, Austria, International Association for Plant Taxonomy. Pp. 171-189.

Groenteman R, Kelly D, Fowler SV, Bourdôt G 2008. Which species of thistle biocontrol agent Trichosirocalus are present in New Zealand? In: Julien M, Sforza R, Bon MC, Evans HC, Hatcher PEet al. Ed. Proceedings of the XII International Symposium on Biological Control of Weeds. La Grande Motte, France, CABI. Pp. 145-149. https://doi.org/10.1079/9781845935061.0145

Harris P, Wilkinson A 1984. Cirsium vulgare (Savi) Ten., Bull Thistle (Compositae). In: Kelleher J, Hulme M Ed. Biological programmes against insects and weeds in Canada 1969-1980. London, Commonwealth Agricultural Bureaux. Pp. 147-153.

Harris P 1989. The use of Tephritidae for the biological control of weeds. Biocontrol News and Information 10: 7-16.

Headrick DH, Goeden RD 1994. Reproductive behavior of California fruit flies and the classification and evolution of Tephritidae (Diptera) mating systems. Studia Dipterologica 1: 194-252.

Hidalgo O, Garcia-Jacas N, Garnatje T, Susanna A 2006. Phylogeny of Rhaponticum (Asteraceae, CardueaeCentaureinae) and related genera inferred from nuclear and chloroplast DNA sequence data: Taxonomic and biogeographic implications. Annals of Botany 97: 705714. https://doi.org/10.1093/aob/mcl029

Hinz HL, Schwarzländer M, Gassmann A, Bourchier RS 2014. Successes we may not have had: a retrospective analysis of selected weed biological control agents in the United States. Invasive Plant Science and Management 7: 565579. https://doi.org/10.1614/IPSM-D-13-00095.1

Hinz HL, Winston RL, Schwarzländer M 2019. How safe is weed biological control? A global review of direct nontarget attack. The Quarterly Review of Biology 94: 1-27. https://doi.org/10.1086/702340

Hinz HL, Winston RL, Schwarzländer M 2020. A global review of target impact and direct nontarget effects of classical weed biological control. Current Opinion in Insect Science 38: 48-54. https://doi.org/10.1016/j. cois.2019.11.006

Kelly D, Popay AI 1985. Pasture production lost to unsprayed thistles at two sites. Proceedings of the NZ Weed and Pest Control Conference 38: 115-118. https://doi. org/10.30843/nzpp.1985.38.9445

Klinkhamer P, G. L. , de Jong TJ 1993. Cirsium vulgare (Savi) Ten. Journal of Ecology 81: 177-191. https://doi. org/10.2307/2261233

Knio KM, Kalash SH, White IM 2002. Flowerhead-infesting fruit flies (Diptera: Tephritidae) on thistles (Asteraceae), in Lebanon. Journal of Natural History 36: 617-629. https://doi.org/10.1080/00222930010023448

Korneyev VA, White IM 2000. Tephritids of the genus Urophora R.-D. (Diptera, Tephritidae) of east Palearctic: IV. (Conclusion). Entomological Review 80: 497-510.

Michaelis H 1986. Competition of Urophora stylata F. and Terellia serratulae L.(Dipt., Tephritidae) in the flowerheads of Cirsium vulgare. In: Mangel M, Carey JR, Plant RE Eds. Pest control: operations and systems analysis in fruit fly management. NATO ASI Series (Series G: Ecological Sciences), vol 11. Berlin, Springer. Pp. 191199. https://doi.org/10.1007/978-3-642-70883-1 14

Morin L, Reid AM, Sims-Chilton NM, Buckley YM, Dhileepan K, Hastwell GT, Nordblom TL, Raghu S 2009. Review of approaches to evaluate the effectiveness of weed biological control agents. Biological Control 51: 1-15. https://doi.org/10.1016/j.biocontrol.2009.05.017

Paynter Q, Fowler SV, Gourlay AH, Haines ML, Harman HM, Hona SR, Peterson PG, Smith LA, Wilson-Davey JRA, Winks CJ, Withers TM 2004. Safety in New Zealand weed biocontrol: a nationwide survey for impacts on nontarget plants. New Zealand Plant Protection 57: 102107. https://doi.org/10.30843/nzpp.2004.57.6979

Paynter Q, Gourlay AH, Oboyski PT, Fowler SV, Hill RL, Withers TM, Parish H, Hona S 2008a. Why did specificity testing fail to predict the field host-range of the gorse pod moth in New Zealand? Biological Control 46: 453462. https://doi.org/10.1016/j.biocontrol.2008.05.004

Paynter Q, Martin N, Berry J, Hona S, Peterson P, Gourlay AH, Wilson-Davey J, Smith L, Winks C, Fowler SV 2008b. Non-target impacts of Phytomyza vitalbae a biological control agent of the European weed Clematis vitalba in New Zealand. Biological Control 44: 248-258. https:// doi.org/10.1016/j.biocontrol.2007.08.003

Paynter Q Fowler SV, Gourlay AH, Peterson PG, Smith LA, Winks CJ 2015. Relative performance on test and target plants in laboratory tests predicts the risk of nontarget attack in the field for arthropod weed biocontrol agents. Biological Control 80: 133-142. https://doi. org/10.1016/j.biocontrol.2014.10.007

Pemberton RW 2000. Predictable risk to native plants in weed biological control. Oecologia 125: 489-494. https://doi.org/10.1007/s004420000477

Redfern M 1968. The natural history of spear thistle-heads. Field Studies 2: 669-717.

Schaffner U 2001. Host range testing of insects for biological weed control: How can it be better interpreted? BioScience 51:951-959. https://doi.org/10.1641/00063568(2001)051[0951:HRTOIF]2.0.CO;2

Schaffner U, Hill M, Dudley T, D’Antonio C 2020. Post-release monitoring in classical biological control of weeds: assessing impact and testing pre-release hypotheses. Current Opinion in Insect Science: 99-106. https://doi. org/10.1016/j.cois.2020.02.008

Sheppard AW, van Klinken RD, Heard TA 2005. Scientific advances in the analysis of direct risks of weed biological control agents to nontarget plants. Biological Control 35: 215-226. https://doi.org/10.1016/j. biocontrol.2005.05.010 
Susanna A, Garcia-Jacas N 2007. Tribe Cardueae Cass. (1819). In: Kubitzki K Ed. The families and genera of vascular plants. Berlin, Springer-Verlag. Pp. 123-147.

Waipara NW, Barton J, Smith LA, Harman HM, Winks CJ, Massey B, Wilkie JP, Gianotti AF, Cripps MG 2009. Safety in New Zealand weed biocontrol: a nationwide pathogen survey for impacts on non-target plants. New Zealand Plant Protection 62: 41-49. https://doi.org/10.30843/ nzpp.2009.62.4804

Wapshere AJ 1989. A testing sequence for reducing rejection of potential biological control agents for weeds. Annals of Applied Biology 114: 515-526. https://doi. org/10.1111/j.1744-7348.1989.tb03367.x

Webb CJ, Sykes WR, Garnock-Jones PJ 1988. Flora of New Zealand. Christchurch, DSIR, Botany Division. 1365 p.

Winston R, Schwarzländer M, Hinz HL, Day M, Cock M, Julien M 2014. Biological Control of Weeds: A World Catalogue of Agents and Their Target Weeds. 5th ed. Morgantown, West Virginia, USDA Forest Service. 838 p.

Withers TM, Hill RL, Paynter Q, Fowler SV, Gourlay AH 2008. Post-release investigations into the field host range of the gorse pod moth Cydia succedana Denis \& Schiffermüller (Lepidoptera: Tortricidae) in New Zealand. New Zealand Entomologist 31: 67-76. https:// doi.org/10.1080/00779962.2008.9722168

Woodburn TL 1993. Host specificity testing, release and establishment of Urophora solstitialis (L.) (Diptera: Tephritidae), a potential biological control agent for Carduus nutans L., in Australia. Biocontrol Science and Technology 3: 419-426. https://doi. org/10.1080/09583159309355296

Zwölfer H 1965. Preliminary list of phytophagous insects attacking wild Cynareae (Compositae) in Europe. Technical Bulletin of the Commonwealth Institute of Biological Control 6: 81-154.

Zwölfer H, Harris P 1984. Biology and host specificity of Rhinocyllus conicus (Fröl.) (Col, Curculionidae), a successful agent for biocontrol of the thistle, Carduus nutans L. Journal of Applied Entomology 97: 36-62. https://doi.org/10.1111/j.1439-0418.1984.tb03714.x 